\title{
NEDESTRUKTIVNA PROCJENA KONCENTRACIJE FOTOSINTETSKIH PIGMENATA U LIŠĆU HRASTA LUŽNJAKA (Quercus robur L.)
}

\section{NONDESTRUCTIVE ESTIMATION OF PHOTOSYNTHETIC PIGMENT CONCENTRATIONS IN PEDUNCULATE OAK (Quercus robur L.) LEAVES}

\author{
Krunoslav SEVER', Saša BOGDAN', Jozo FRANJIĆ ${ }^{1}$,̌eljko ŠKVORC ${ }^{1}$
}

\begin{abstract}
Sažetak
U radu je predstavljena nedestruktivna procjena koncentracije fotosintetskih pigmenata (ukupnih klorofila i karotenoida) u lišću hrasta lužnjaka pomoću prijenosnog optičkog klorofilmetra CCM-200. Istraživanje je provedeno 2015. godine na biljnom materijalu izloženom različitim tretmanima vlažnosti tla. U kontrolnom tertmanu sadržaj vlage u tlu održavan je iznad poljskog vodnog kapaciteta, dok je u sušnom tretmanu biljkama voda bila uskraćena 112 dana (1. 4. - 21. 7.). U drugom dijelu vegetacijskog razdoblja (22. 7. - 22. 10.) u oba tretmana vlaga tla održavana je iznad poljskog vodnog kapaciteta. Na temelju lišća uzorkovanoga istovremeno u oba tretmana i to sredinom jeseni (27. 10.) izrađene su kalibracijske jednadžbe koje opisuju odnos indeksa relativnog sadržaja klorofila izmjerenoga pomoću klorofilmetra i stvarne koncentracije fotosintetskih pigmenata (utvrđene laboratorijski) pred sam kraj vegetacijskog razdoblja. Jednadžbe su konstruirane posebno za kontrolni, a posebno za sušni tretman. S obzirom na takav dizajn pokusa i vrijeme uzorkovanja, primarni cilj rada bio je ispitati utjecaj dugotrajnog sušnog razdoblja na homogenost parametara kalibracijskih jednadžbi (Y-odsječaka i nagiba pravaca). Na temelju dobivenih rezultata zaključeno je da parametri kalibracijskih jednadžbi nisu bili utjecani sušnim tretmanom. Prema tome, rezultati istraživanja ukazuju na to da klorofilmetar CCM-200, uz primjenu odgovarjućih kalibracijskih jednadžbi, predstavlja pouzdan alat za nedestruktivnu procjenu koncentracije ukupnih klorofila i karotenoida u lišću hrasta lužnjaka, bez obzira na različite režime vlažnosti tla kojima je biljni materijal bio izložen tijekom vegetacijskog razdoblja. Uz to, u radu je utvrđeno da bi preciznost procjene stvarne koncentracije fotosintetskih pigmenata bilo moguće i dodatno poboljšati korekcijom klorofilnog indeksa sa specifičnom lisnom masom.
\end{abstract}

KLJUČNE RIJEČI: Klorofilmetar CCM-200, indeks relativnoga sadržaja klorofila u lišću, specifična lisna masa, ukupni klorofili, karotenoidi

\section{UVOD}

\section{INTRODUCTION}

Sadržaj i/ili koncentracija fotosintetskih pigmenata (klorofila i karotenoida) u lišću šumskoga drveća dobar je indika- tor, učinkovitosti fotosintetskog aparata (Peñuelas i Filella 1998), razine ishranjenosti dušičnim hranivima (Cate i Perkins 2003; Chang i Robison 2003; Percival i dr. 2008) i jesenskog starenja lišća (Fridley 2012; Arend i dr. 2016a,

\footnotetext{
1 Dr. sc. .Krunoslav Sever, Izv. prof. dr. sc. Saša Bogdan, Prof dr. sc. Jozo Franjić, Izv. prof. dr. sc. Željko Škvorc, Šumrski fakultet, Sveučilište u Zagrebu. Zavod za šumarsku genetiku, dendrologiju i botaniku. Svetošimunska 25, HR-10000 Zagreb

Korespodencija: Krunoslav Sever, e-mail:ksever@sumfak.hr
} 
2016b). Na temelju negativnih promjena u koncentraciji fotosintetskih pigmenata te promjeni njihova odnosa moguće je detektirati prisutnost okolišnog stresa mnogo prije manifestacije simptoma vidljivih golim okom (Percival i dr. 2008). Pravovremena detekcija pojave okolišnog stresa često puta ima odlučujuću ulogu u sprječavanju značajnijih šteta prilikom uzgoja sadnog materijala u šumskim rasadnicima (Seletković 2006; Schmal i dr. 2011) te gubitka prirasta drvne mase u šumskim kulturama i plantažama (Baule i Fricker 1970; Potočić 2006).

Tradicionalne laboratorijske metode za utvrđivanje koncentracije fotosintetskih pigmenata u lišću predstavljaju osnovnu prepreku za provođenje kontinuiranog monitoringa koncentracije fotosintetskih pigmenata u šumskim rasadnicima, kulturama i plantažama, ponajprije iz razloga što su relativno skupe, dugo traju i zahtijevaju destrukciju biljnoga materijala prilikom uzimanja uzoraka (Van den Berg i Perkins 2004). Međutim, procjena koncentracije fotosintetskih pigmenata u lišću šumskog drveća pomoću prijenosnih optičkih klorofilmetara kao što su CCM-200 (OptiSciences, Tyngsboro, Massachusetts, USA) i SPAD-502 (Minolta Camera Co., Osaka, Japan) predstavlja pouzdanu alternativu tradicionalnim laboratorijskim metodama (Cate i Perkins 2003; Chang i Robison 2003; Van den Berg i Perkins 2004; Percival i dr. 2008; Silla i dr. 2010).

Da bi se klorofilmetar mogao koristiti u tu svrhu potrebno je najprije konstruirati kalibracijske jednadžbe (regresijske jednadžbe) koje pouzdano opisuju odnos između indeksa relativnog sadržaja ukupnih klorofila u lišću (eng. Chlorophyll Content Index - CCI) očitanoga pomoću klorofilmetra (Chang i Robison 2003; Silla i dr. 2010) i ukupne količine fotosintetskih pigmenata, utvrđene nekom od standardnih laboratorijskih metoda (Bruisna 1961; Hiscox i Israelstam 1979; Inskeep i Bloom 1985; Lichtenthaler 1987). Na taj je način, u dosadašnjim istraživanjima regresijskom analizom dokazana snažna veza između CCI-a i ukupnog sadržaja i/ ili koncentracije klorofila (Cate i Perkins 2003; Silla i dr. 2010) i karotenoida (Torres Neto i dr. 2005; Percival i dr. 2008). Na temelju toga, klorofilmetar se smatra korisnim alatom za brzu, jednostavnu, jeftinu i nedestruktivnu procjenu ukupnog sadržaja i/ili koncentracije fotosintetskih pigmenata u lišću šumskog drveća. Upravo to mu daje prednost u odnosu na laboratorijske metode te olakšava provođenje kontinuiranog monitoringa koncentracije fotosintetskih pigmenata u šumskim rasadnicima, kulturama i/ili plantažama.

Unatoč navedenim prednostima, nedestruktivna procjena koncentracije fotosintetskih pigmenata pomoću klorofilmetra ima i određena ograničenja. Ta ograničenja ponajprije se ogledaju u očitanju previsokih ili preniskih vrijednosti CCI-a u odnosu na stvarni sadržaj klorofila u lišću. To je najčešće posljedica promjene optičkih značajki lišća koje uvelike ovise o njegovim strukturnim značajkama (gustoća i debljina parenhima, sadržaj vlage u lišću i dr.) što može značajno utjecati na odnos CCI-a i koncentracije fotosintetskih pigmenata (Richardson i dr. 2002, Silla i dr. 2010). Strukturne značajke lišća pod utjecajem su velikoga broja okolišnih čimbenika (Jifon i dr. 2005), uključujući i dugotrajna sušna razdoblja (Aspelmeier 2001).

U skladu s tim, cilj ovoga istraživanja bio je: (i) utvrditi da li dugotrajno sušno razdoblje značajno utječe na odnos između klorofilnog indeksa očitanog pomoću klorofilmetra CCM-200 i koncentracije fotosintetskih pigmenata (ukupnih klorofila i karotenoida); (ii) konstruirati kalibracijske jednadžbe za nedestruktivnu procjenu koncentracije fotosintetskih pigmenata u lišću hrasta lužnjaka; (iii) ispitati da li je moguće na temelju korigiranoga klorofilnog indeksa sa specifičnom lisnom masom povećati preciznost procjene koncentracije fotosintetskih pigmenata.

\section{MATERIJALI I METODE MATERIAL AND METHODS}

\section{Biljni materijal i područje istraživanja - Plant material and research area}

Istraživanje je provedeno tijekom 2015. godine na 60 dvogodišnjih biljaka hrasta lužnjaka uzgajanih u plasteniku Hrvatskog Šumarskog Instituta Jastrebarsko. Žir iz kojega je biljni materijal uzgojen sakupljen je 2013. godine u devet prirodnih populacija hrasta lužnjaka s područja Europe (Estonija, Litva, Poljska, Mađarska, Hrvatska i Italija). Tijekom istraživanja bilike su rasle u 50 litarskim posudama prethodno ispunjenim sa tlom porijeklom iz prirodne lužnjakove sastojine. U proljeće 2015. godine neposredno prije početka istraživanja prosječna visina istraživanih biljaka iznosila je 23,9 $\pm 4,8 \mathrm{~cm}$.

\section{Dizajn pokusa - Experiment design}

Istraživanje je započelo 1. travnja 2015. godine u plasteniku koji je bio opremljen automatskim sustavima za provjetravanje i hlađenje s ciljem održavanja temperature i relativne vlažnosti zraka u skladu s vanjskim prirodnim uvjetima. $U z$ to, plastenik je bio opremljen sustavom za modularno navodnjavanje biljnoga materijala po principu "kap po kap". Zahvaljujući tomu, posude sa biljkama unutar plastenika bile su izložene različitim tretmanima vlaženja tla, dok su ostali okolišni uvjeti (temperatura i relativna vlažnost zraka) bili ujednačeni u oba tretmana (Slika 1). Jedan od tretmana bio je kontrolni, u kojemu su bilike bile kontinuirano zalijevane svaki drugi ili treći dan sa četiri litre vode po posudi. U kontrolnom tretmanu, na taj je način sadržaj vlage u tlu održavan iznad poljskog vodnog kapaciteta (1. travnja - 27. listopada). Drugi je bio sušni tretman u kojemu je biljkama voda bila uskraćena 112 dana (1. travnja - 21. srpnja). To dugotrajno sušno razdoblje prekinuto je ponovnim zalije- 


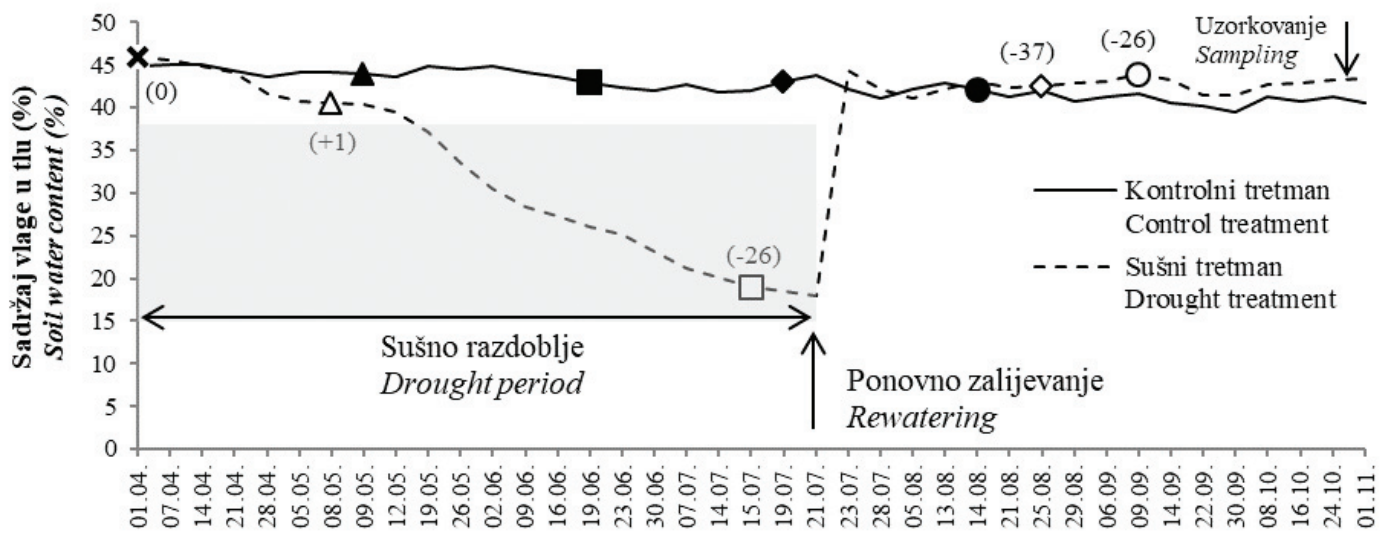

\section{Datum - Date}

Slika 1. Sadržaj vlage u tlu kontrolnog i sušnog tretmana. Sivo područje ukazuje na trajanje sušnog razdoblja od 1. travnja do 21. srpnja i raspon vlage tla od 38 \% (poljski vodni kapacitet) do $15 \%$ (permanentna točka venuća). Prosječni početak rasta vršnoga izbojka u vrijeme proljetnoga porasta $(\times)$ u oba tretmana. Prosječni početak rasta vršnoga izbojka u vrijeme prvoga $(\triangle)$, drugoga $(\square)$, trećeg $(\diamond)$ i četvrtog $(\bigcirc)$ ljetnog porasta. Ispunjeni simboli se odnose na kontrolni a prazni simboli na sušni tretman. Vrijednosti u zagradi ukazuju na prosječnu razliku u broju dana između kontrolnoga i sušnoga tretmana s obzirom na prosječni početak razvoja vršnog izbojka.

Figure 1. Soil water content in control and drought treatment. The gray area indicates the duration of the drought period from $1^{\text {st }} \mathrm{April}$ to $21^{\text {st }} \mathrm{July}$, as well as soil moisture content range from 38\% (field water capacity) to 15\% (permanent wilting point). Average start of the spring flush $(\times)$ in both treatments. Average start of the first $(\triangle)$, second $(\square)$, third $(\diamond)$ and the fourth $(\bigcirc)$ summer growth flush in control (closed simbols) and drought treatment (open simbols). Values in parathensis indicate difference between the average number of days in start of leader shoot development between control and drought treatment.

vanjem $\mathrm{u}$ trenutku kada su biljke počele pokazivati vidljive simptome sušnoga stresa (venuće i/ili žućenje lišća). Nakon toga, biljke iz sušnoga tretmana bile su izložene jednakom režimu vlaženja kao i biljke iz kontrolnog tretmana, što je održavano sve do kraja istraživanja, 27. listopada 2015. godine (Slika 1).
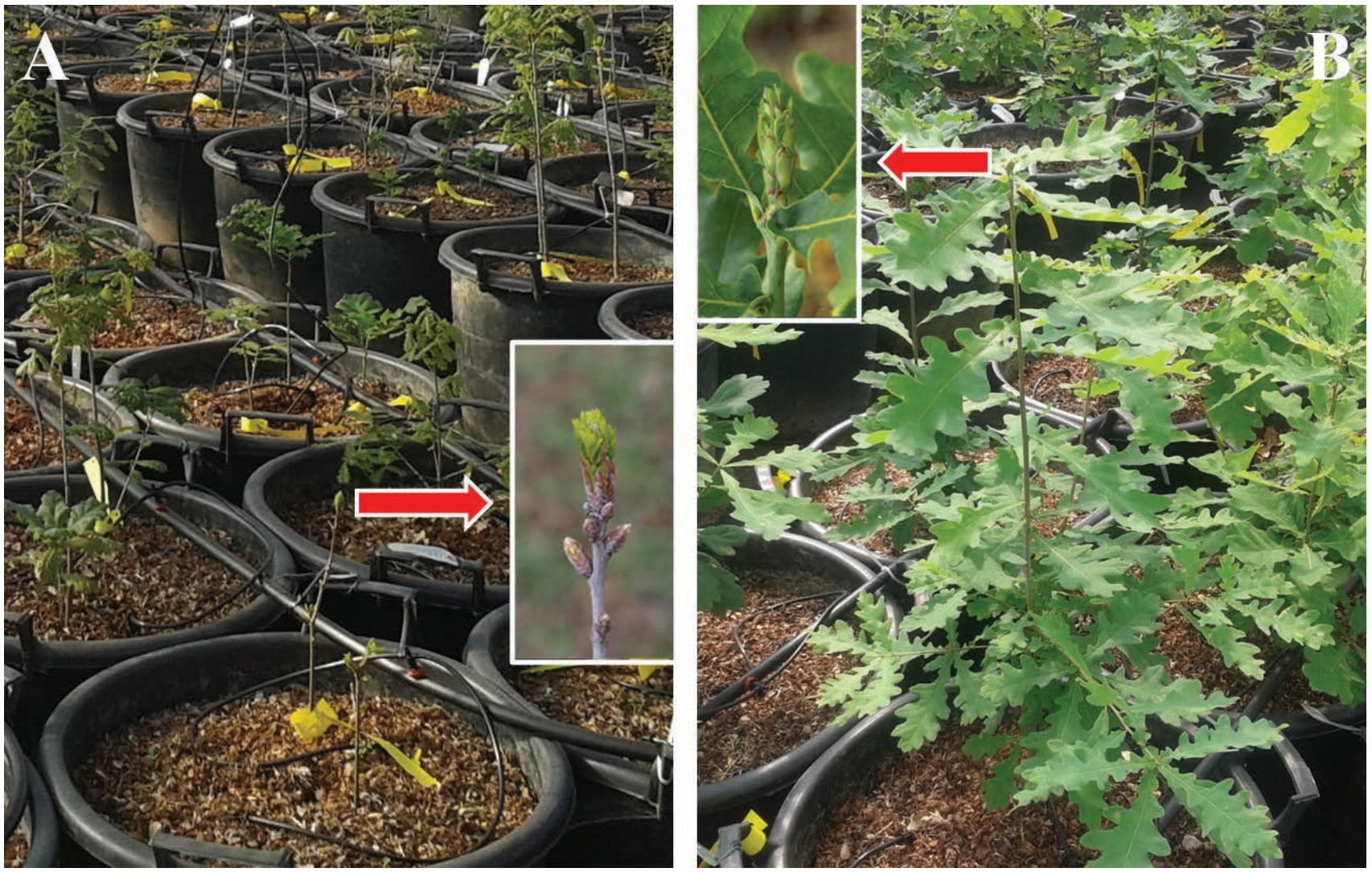

Slika 2. Fenofaze vršnih pupova na temelju kojih je utvrđen početak razvoja vršnoga (vodećeg) izbojka u vrijeme proljetnog porasta (A) te u vrijeme prvoga, drugoga, trećega i četvrtoga ljetnoga porasta (B).

Figure 2. Phenological phases of the apical buds which used for the determine the start of the leading shoot development, at the time of the spring flush (A) and during the summer first, second, third and fourth flush (B). 
Izmjera sadržaja vlage u tlu i vodnog potencijala u lišću - Measurement of soil water content and water potential in leaves

Sadržaj vlage u tlu mjeren je pomoću senzora (EC-5 soil water sensor, Decagon Devices, Inc., Pullman, USA) povezanih s ukupno tri automatske meteorološke postaje $\left(\mathrm{ECH}_{2} \mathrm{O}\right.$, Decagon Devices, Inc., Pullman, USA) instalirane u plasteniku. Svaka meteorološka postaja bila je povezana sa četiri senzora za izmjeru vlage u tlu (dva u kontrolnom i dva u sušnom tretmanu) postavljenih u zasebne posude, na dubinu $10-15 \mathrm{~cm}$.

Vodni potencijal u lišću $(\psi)$, mjeren je na vrhuncu sušnoga stresa (21. srpnja) pred zoru, na jednom listu po biljci, pomoću prijenosne konzole za izmjeru vodnog potencijala (M 600; Mosler Tech Support. Berlin, Germany).

\section{Razvoj biljaka, uzorkovanje lišća i konstrukcija kalibracijskih jednadžbi - Plant growth, sampling of leaves and construction of calibration equations}

Vegetativni rast istraživanih biljaka praćen je na temelju fenoloških motrenja koja su obavljana jednom tjedno tijekom vegetacijskoga razdoblja. Tom prilikom, uz standardni pro-

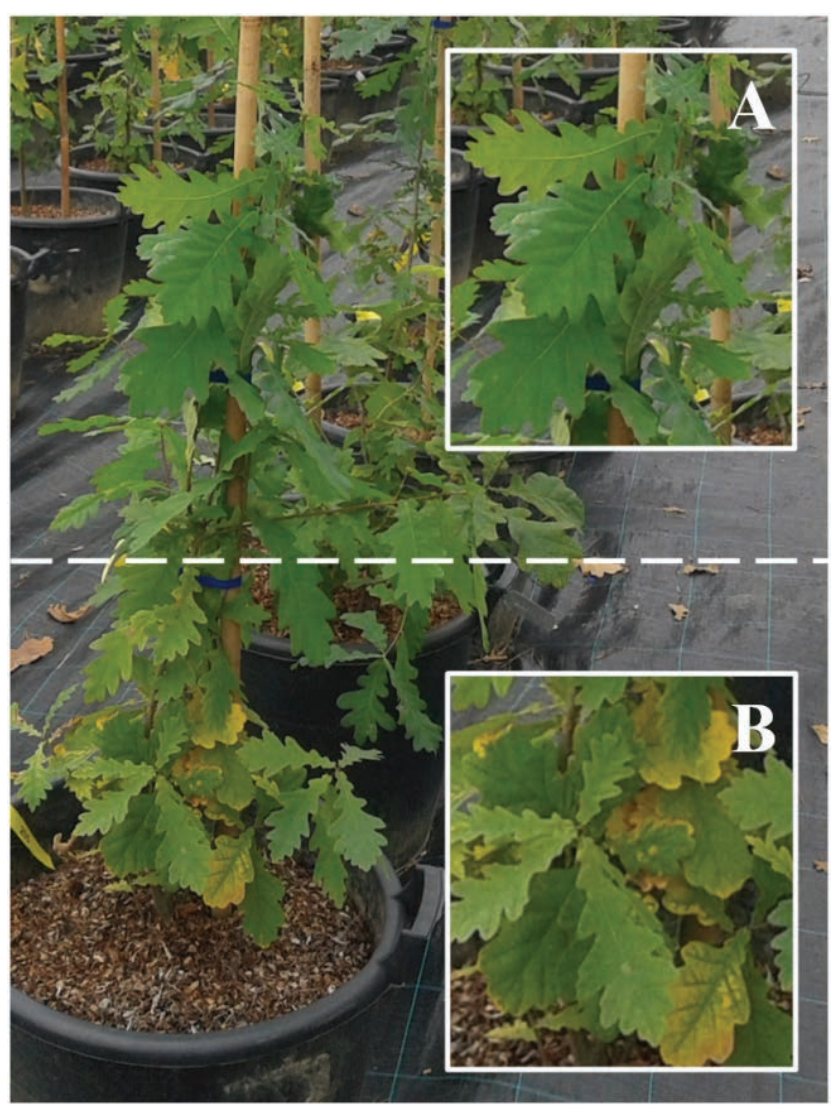

Slika 3. Tipičan izgled istraživanih biljaka tijekom uzorkovanja lišća 27. listopada 2015. godine. Izgled uzorkovanog lišća iz gornjega dijela krošnje (A) te izgled uzorkovanoga lišća iz donjega dijela krošnje (B).

Figure 3. Typical appearance of the investigated plants during the leaves sampling on $27^{\text {th }}$ October 2015. The appearance of the sampled leaves from the upper part of the crown (A) and from the lower part of the crown (B) ljetni porast, bilježen je početak i završetak prvog, drugog, trećeg i četvrtog ljetnog porasta vršnog (vodećeg) izbojka s pripadajućim lišćem (Slika 2).

Uzorkovanje lišća što podrazumijeva izmjeru klorofilnoga indeksa u lišću (CCI) pomoću klorofilmetra (in situ) i njegovo sakupljanje za potrebe laboratorijskih analiza obavljeno je pred sam kraj vegetacijskoga razdoblja (27. listopada 2015. godine).

Ukupno je uzorkovano 60 listova porijeklom sa 60 biljaka (jedan list po biljci). Od toga je 26 listova uzorkovano u kontrolnom, a 34 lista u sušnom tretmanu. U oba tretmana, birano je lišće u rasponu boja od blijedo žute, što ukazuje na nisku koncentraciju klorofila do tamno zelene, što ukazuje na visoku koncentraciju klorofila u lišću (Slika 3).

Na temelju tako uzorkovanoga lišća konstruirane su po dvije kalibracijske jednadžbe (linearne regresijske jednadžbe) koje opisuju odnos između CCI-a i ukupnih klorofila, odnosno karotenoida u lišću porijeklom $s$ biljaka iz kontrolnoga, odnosno sušnoga tretmana.

\section{Izmjera klorofilnog indeksa i specifične lisne mase - Measurement of chlorophyll content index and specific leaf mass}

Izmjera klorofilnog indeksa (CCI) obavljena je pomoću prijenosnog optičkog klorofilmetra CCM-200 (Opti-sciences, Tyngsboro, Mass.). Princip rada i osnovne značajke samog uređaja detaljno su opisali Cate i Perkins (2003) te Silla i dr. (2010). Na svakom uzorkovanom listu obavljeno je pet očitanja CCI-a, čiji je prosjek predstavljao CCI uzorkovanog lista. Lišće je nakon toga sakupljeno i smješteno u prijenosni hladnjak na temperaturu zraka od $4{ }^{\circ} \mathrm{C}$ sve do dolaska u laboratorij. Po dolasku u laboratorij svakom je listu utvrđena masa svježe tvari pomoću analitičke vage s točnošću od 0,01 g. Nakon toga, lišću je izmjerena površina pomoću programskog paketa WinFOLIA (WinFolia 2005b). Na temelju podataka o masi svježe tvari i površine lišća, svakom uzorkovanom listu utvrđena je specifična lisna masa (LMA), što predstavlja masu svježe tvari lista po jedinici površine lista. Korigirani klorofilni indeks $\left(\mathrm{CCI} \mathrm{LMA}{ }^{-1}\right)$ izračunat je kao međusobni odnos izmjerenih vrijednosti CCI-a i utvrđene LMA za svaki uzorkovani list.

\section{Laboratorijsko utvrđivanje koncentracije klorofila i karotenoida - Laboratory estimation of chlorophyll and carotenoid concentrations}

Koncentracija ukupnih klorofila i karotenoida utvrđena je u svakom uzorkovanom listu pojedinačno (svaki list predstavljao je zasebni uzorak). Usitnjeno lišće je homogenizirano tekućim dušikom u tarioniku. Sa $0,1 \mathrm{~g}$ tako pripremljenog praha ispunjene su prethodno pripremljene Eppendorf kivete zapremnine 0,2 $\mathrm{ml} \mathrm{uz}$ dodatak hladnog acetona (80\%). Tkivo je nakon toga ekstrahirano 15 minuta 
u hladnjaku, nakon čega je centrifugirano na 1000 okretaja u 10 minuta. Supernatant je dekantiran u plastične epruvete, a kruti ostatak zelene boje reekstrahiran je s acetonom sve dok tkivo nije izgubilo zelenu boju. Nakon toga, pomoću menzure izmjeren je volumen svakog uzorka. Tako pripremljeni uzorci korišteni su za spektrofotometrijsko mjerenje na UV/VIS spektrofotometru (Specord 40, Analytic Jena) pomoću kojega je izmjerena apsorbancija uzoraka na valnim duljinama od $661,6 \mathrm{~nm} ; 664,8 \mathrm{~nm}$ i $470 \mathrm{~nm}$. $\mathrm{Na}$ temelju poznate lisne mase $(\mathrm{m})$, volumena $(\mathrm{V})$ i apsorbancije (A) pri određenoj valnoj duljini izračunate su koncentracije fotosintetskih pigmenata u svakom uzorku pomoću sljedećih formula (Lichtenthaler 1987):

Koncentracija ukupnih klorofila $(\mathrm{a}+\mathrm{b})=$ $\left(7.05 \cdot \mathrm{A}_{661.6 \mathrm{~nm}}+18.09 \cdot \mathrm{A}_{644.8 \mathrm{~nm}}\right) \cdot \mathrm{V} /(\mathrm{m} \cdot 1000)$,

iskazano u $\mathrm{mg} \mathrm{g}^{-1}$ svježe tvari uzorka.

Koncentracija ukupnih karotenoida $=$ $\left(1000 \cdot \mathrm{A}_{470 \mathrm{~nm}}-1.90 \cdot\left(11.24 \cdot \mathrm{A}_{661.6 \mathrm{~nm}}\right)-2.04 \cdot \mathrm{A}_{64.8 \mathrm{~nm}}\right)$ $\left.-63.14 \cdot\left(20.13 \cdot \mathrm{A}_{644.8 \mathrm{~mm}}\right)-4.19 \cdot \mathrm{A}_{661.6 \mathrm{~mm}}\right) \cdot \mathrm{V} /(214 \cdot \mathrm{m} \cdot 1000)$, iskazano u $\mathrm{mg} \mathrm{g}^{-1}$ svježe tvari uzorka.

\section{Statistička analiza - Statistical analysis}

Student-ov t-test proveden je s ciljem utvrđivanja razlika ( $p<$ $0,05)$ između tretmana s obzirom na izmjerene vrijednosti klorofilnog indeksa, koncentracije klorofila, koncentracije karotenoida, vodnoga potencijala i specifične lisne mase.

Regresijska analiza provedena je pomoću REG procedure u SAS/STAT 9,3 softverskom paketu (SAS Institute Inc., Cary, NC, USA). Linearne regresijske jednadžbe konstruirane su na način da je CCI, odnosno CCI LMA-1 predstavljao nezavisnu varijablu, a koncentracija klorofila, odnosno karotenoida zavisnu varijablu.

Analiza kovarijance (ANCOVA) provedena je pomoću JMP 9,0 softverskog paketa (SAS Institute Inc., Cary, NC, USA), uključujući analizu interakcije s ciljem ispitivanja homogenosti Y-odsječaka i nagiba pravaca linearnih regresijskih jednadžbi konstruiranih na temelju lišća porijeklom iz kontrolnog i sušnog tretmana.

\section{REZULTATI RESULTS}

\section{Sadržaj vlage u tlu i vodni potencijal u lišću - Soil water content and water potential in leaves}

Tijekom istraživanja, vlaga u tlu kontrolnog tretmana nije se spuštala ispod razine poljskog vodnog kapaciteta, odnosno ispod $38 \%$. U sušnom tretmanu, tijekom sušnog razdoblja vlaga tla je postupno opadala te je na kraju sušnog razdoblja dosegla vrijednost od $18 \%$ (Slika 1). U skladu s tim, tijekom istraživanja vodni potencijal u lišću kontrolnih biljaka bio je prilično stabilan i visok. Međutim, na kraju sušnoga razdoblja (21. srpanj) u lišću sušom tretiranih biljaka vodni potencijal dosegao je vrlo niske vrijednosti, koje su bile statistički značajno niže nego u lišću kontrolnih biljaka (Tablica 1). Nakon što su biljke iz sušnog tretmana ponovno zalivene došlo je do naglog i potpunog oporavka vlage u tlu koja je porasla do razine regularno zalijevanih biljaka iz kontrolnoga tretmana. Zahvaljujući tomu, do kraja vegetacijskoga razdoblja biljke iz oba tretmana rasle su u tlu dobro opskrbljenom vodom, čija vlaga tla više nije opadala ispod razine poljskog vodnog kapaciteta (Slika 1), a vodni potencijal $u$ lišću bio je stabilan i visok.

\section{Rast biljaka - Plant growth}

Prosječni početak vegetativnog rasta, odnosno početak razvoja proljetnih izbojaka u oba tretmana započeo je na isti dan. Pojava prvog ljetnog porasta zabilježena je svega jedan dan ranije u sušnom nego u kontrolnom tretmanu. Među-

Tablica 1. Rezultati studentova t-testa kojim je ispitana statistička značajnost razlika (pri razini signifikantnosti; $p<0,05$ ) između kontrolnog i sušnog tretmana, s obzirom na: prosječne vrijednosti klorofilnoga indeksa (CCI), koncentraciju klorofila i karotenoida u svježoj tvari lišća, specifičnu lisnu masu (LMA) i vodni potencijal $(\psi)$ mjeren 21. srpnja. Prosječna vrijednost \pm S.D. U zagradi je prikazan raspon apsolutnih vrijednosti mjerenih svojstava, od minimalne do maksimalne.

Table 1. The results of the student's t-test used for testing significance of differences (level of significance, $p<0.05$ ) between the control and the drought treatment, considering the average of chlorophyll content index (CCI), chlorophyll and carotenoid concentrations in fresh weight (FW) of leaves, specific leaf mass (LMA) and water potential $(\psi)$ measured on July $21^{\text {st }}$. Mean value \pm S.D. Values in the parenthesis, indicate the range of absolute values of measured traits, ranging from minimum to maximum.

\begin{tabular}{|c|c|c|c|c|}
\hline $\begin{array}{l}\text { Mjerena svojstva } \\
\text { Measured traits }\end{array}$ & $\begin{array}{l}\text { Kontrolni tretman }(n=26) \\
\text { Control treatment }\end{array}$ & $\begin{array}{c}\text { Sušni tretman }(\mathrm{n}=34) \\
\text { Drought treatment }\end{array}$ & $\begin{array}{c}\mathrm{t} \text { - vrijednost } \\
t \text { - values }\end{array}$ & $\mathrm{p}$ \\
\hline CCI & $13,1 \pm 6,8(1,5-25,1)$ & $21,3 \pm 10,4(3,4-38,4)$ & $-3,48$ & 0,001 \\
\hline $\begin{array}{l}\text { Klorofil (mg g-1 SvT) } \\
\text { Chlorophyll (mg g } \text { g }^{-1} \text { FW) }\end{array}$ & $1,18 \pm 0,65(0,02-2,20)$ & $1,73 \pm 0,89(0,11-2,90)$ & $-2,64$ & 0,011 \\
\hline $\begin{array}{l}\text { Karotenoidi (mg g-1 SvT) } \\
\left.\text { Carotenoids ( } \mathrm{mg} \mathrm{g}^{-1} \mathrm{FW}\right)\end{array}$ & $0,56 \pm 0,15(0,30-0,80)$ & $0,69 \pm 0,18(0,26-0,90)$ & $-2,97$ & 0,004 \\
\hline LMA $\left(\mathrm{g} \mathrm{m}^{-2}\right)$ & $125,6 \pm 18,6(90,2-168,3)$ & $133,6 \pm 17,8(101,5-174,1)$ & $-1,69$ & 0,097 \\
\hline $\begin{array}{l}\psi(\mathrm{MPa}) \text { 21. Srpanj } \\
\psi(\mathrm{MPa}) \text { July } 21^{\text {st }}\end{array}$ & $-0,38 \pm 0,19((-0,1)-(-0,9))$ & $-2,51 \pm 1,34((-0,5)-(-4,0))$ & $-9,84$ & $<0,001$ \\
\hline
\end{tabular}



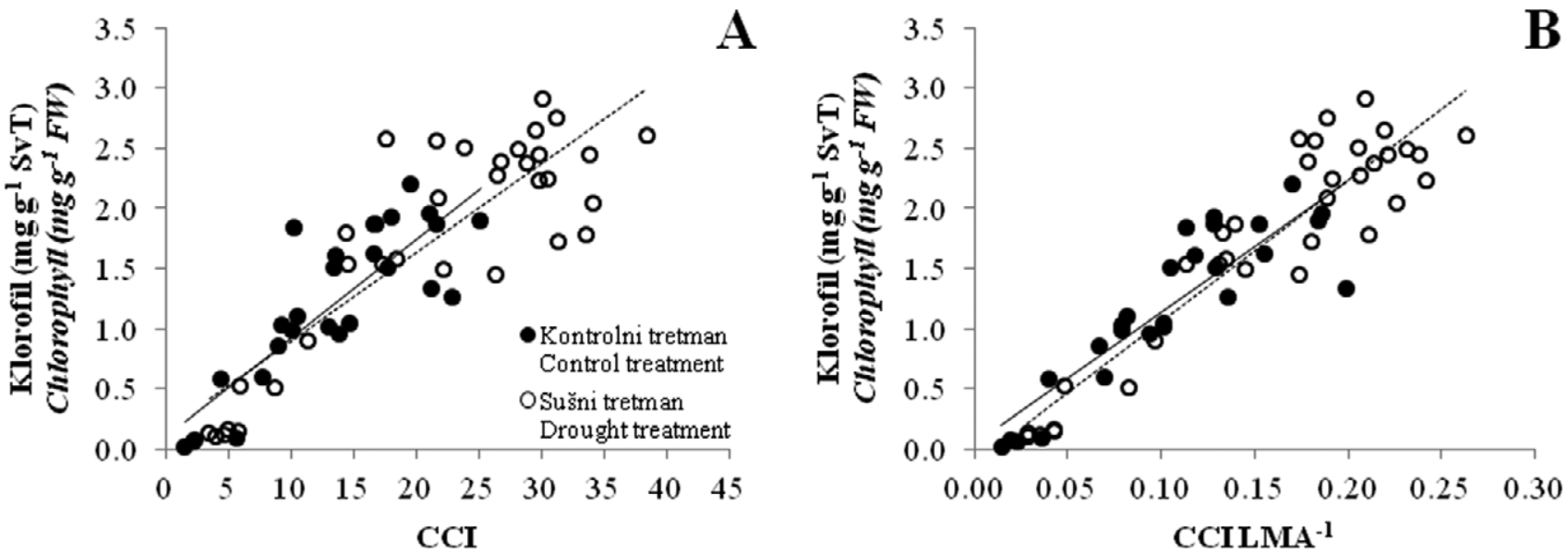

Slika 4. Linearni odnos između koncentracije klorofila u svježoj tvari (SvT) uzorkovanoga lišća i klorofilnog indeksa (CCI) u lišću porijeklom iz kontrolnog (puna linija) i sušnog (isprekidana linija) tretmana (A). Linearni odnos između koncentracije klorofila u svježoj tvari (SvT) uzorkovanoga lišća i klorofilnog indeksa korigiranog sa specifičnom lisnom masom (CCI LMA-1) u lišću porijeklom iz kontrolnog (puna linija) i sušnog (isprekidana linija) tretmana (B).

Figure 4. The linear relationship between the chlorophyll concentrations in the fresh weight (FW) of the sampled leaves and the chlorophyll content index (CCI) in leaves of the control (solid line) and drought (dash line) treatments (A). The linear relationship between the chlorophyll concentrations in the fresh weight (FW) of the sampled leaves and the chlorophyll content index corrected with the specific leaf mass (CCI LMA ${ }^{-1}$ ) in leaves of the control (solid line) and drought (dash line) treatment (B).

tim, drugi, treći i četvrti ljetni porast vršnoga izbojka zabilježen je mnogo kasnije u sušnom nego u kontrolnom tretmanu (Slika 1).

Razlike između tretmana s obzirom na klorofilni indeks, specifičnu lisnu masu, koncentraciju klorofila i karotenoida - Differences between treatments in according to chlorophyll content index, specific leaf mass, chlorophyll and carotenoid concentrations

U lišću porijeklom iz kontrolnog tretmana prosječne koncentracije klorofila i karotenoida te prosječna vrijednost CCI-a bile su statistički značajno niže nego u lišću porijeklom iz sušnoga tretmana. Rasponi apsolutnih vrijednosti (min - max) koncentracije klorofila i karotenoida te izmje- renoga CCI-a bili su manji u lišću kontrolnih nego sušom tretiranih biljaka. Prosječna vrijednost specifične lisne mase također je bila niža u kontrolnom nego u sušnom tretmanu, ali ne i statistički značajno (Tablica 1).

\section{Odnos između klorofilnog indeksa i koncentracije klorofila - Relationship between chlorophyll contetnt index and chlorophyll concentration}

Kod lišća porijeklom iz oba tretmana između izmjerenih vrijednosti CCI-a i koncentracije klorofila utvrđene su visoko signifikantne $(p<0,001)$ korelacije. Koeficijenti determinacije $\left(r^{2}\right)$ ukazuju da je u lišću kontrolnih i sušom tretiranih biljaka 71 i $74 \%$ varijacije u koncentraciji klorofila objašnjeno na temelju izmjerenih vrijednosti CCI-a (Slika 4a i Tablica 2).

Tablica 2. Kalibracijske jednadžbe (linearne regresijske jednadžbe) konstruirane na temelju klorofilnoga indeksa (CCI), odnosno klorofilnoga indeksa korigiranog sa specifičnom lisnom masom $\left(\mathrm{CCI} \mathrm{LMA}^{-1}\right)$ i stvarne koncentracije ukupnih klorofila u lišću biljaka porijeklom iz kontrolnog i sušnog tretmana. Jednadžbe pretvaraju klorofilni indeks (CCI) u koncentraciju ukupnih klorofila u lišću (Chl).

Table 2. Calibration equations (linear regression equations) constructed based on the chlorophyll content index (CCI), as well as chlorophyll content index corrected by specific leaf mass $\left(\mathrm{CCl} \mathrm{LMA}^{-1}\right)$ and the actual concentrations of total chlorophyll in leaves of plants originating from control and drought treatment. The equations convert the chlorophyll content index (CCI) into the total chlorophyll concentration in leaves (Chl).

\begin{tabular}{|c|c|c|c|c|c|c|}
\hline $\begin{array}{l}\text { Porijeklo uzorkovanoga lišća } \\
\text { Origin of the sampled leaves }\end{array}$ & $\begin{array}{l}\text { Jednadžbe s CCI kao } \\
\text { nezavisnom varijablom } \\
\text { Equations with CCI as } \\
\text { independent variable }\end{array}$ & $p$ & $r^{2}$ & $\begin{array}{c}\text { Jednadžbe s CCI LMA-1 } \\
\text { kao nezavisnom varijablom } \\
\text { Equations with CCI LMA'-1 as } \\
\text { independent variable }\end{array}$ & $p$ & $r^{2}$ \\
\hline $\begin{array}{l}\text { Kontrolni tretman }(\mathrm{n}=26) \\
\text { Control treatment }\end{array}$ & $\mathrm{Chl}=0,082 \cdot \mathrm{CCl}+0,11$ & $<0,001$ & 0,71 & $\mathrm{Chl}=10,965 \cdot \mathrm{CCl} \mathrm{LMA}{ }^{-1}+0,04$ & $<0,001$ & 0,78 \\
\hline $\begin{array}{l}\text { Sušni tretman }(\mathrm{n}=34) \\
\text { Drought treatment }\end{array}$ & $\mathrm{Chl}=0,073 \cdot \mathrm{CCl}+0,17$ & $<0,001$ & 0,74 & $\mathrm{Chl}=11,801 \cdot \mathrm{CCl} \mathrm{LMA}^{-1}-0,12$ & $<0,001$ & 0,86 \\
\hline $\begin{array}{l}\text { Oba tretmana }(n=60) \\
\text { Both treatments }\end{array}$ & $\mathrm{Chl}=0,074 \cdot \mathrm{CCl}+0,18$ & $<0,001$ & 0,76 & $\mathrm{Chl}=11,365 \cdot \mathrm{CCl} \mathrm{LMA}^{-1}-0,03$ & $<0,001$ & 0,85 \\
\hline
\end{tabular}



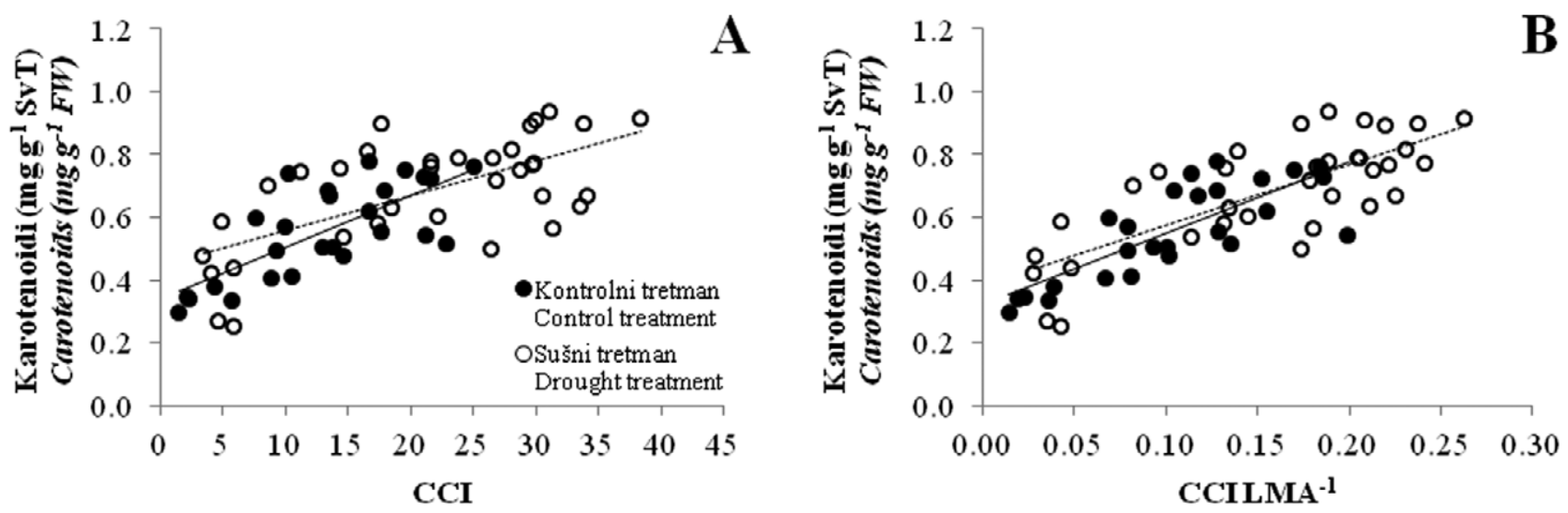

Slika 5. Linearni odnos između koncentracije karotenoida u svježoj tvari (SvT) uzorkovanog lišća i klorofilnog indeksa (CCI) u lišću porijeklom iz kontrolnog (puna linija) i sušnog (isprekidana linija) tretmana (A). Linearni odnos između koncentracije karotenoida u svježoj tvari (SvT) uzorkovanoga lišća i klorofilnog indeksa korigiranog sa specifičnom lisnom masom (CCI LMA ${ }^{-1}$ ) u lišću porijeklom iz kontrolnog (puna linija) i sušnog (isprekidana linija) tretmana (B).

Figure 5. The linear relationship between the carotenoids concentrations in the fresh weight (FW) of the sampled leaves and the chlorophyll content index (CCI) in leaves of the control (solid line) and drought (dash line) treatments (A). The linear relationship between the carotenoid concentrations in the fresh weight (FW) of the sampled leaves and the chlorophyll content index corrected with the specific leaf mass (CCI LMA-1) in leaves of the control (solid line) and drought (dash line) treatment (B).

Na temelju korigiranoga CCI-a sa LMA moguće je objasniti čak 78 \% (lišće kontrolnih biljaka) i $86 \%$ (lišće sušom tretiranih biljaka) varijacije u koncentraciji klorofila (Slika $4 \mathrm{~b}$ i Tablica 2).

Prema rezultatima ANCOVA-e utjecaj tretmana na parametre kalibracijskih jednadžbi (nagibe pravaca i Y odsječke) koje opisuju odnos između CCI-a i koncentracije klorofila nije bio statistički značajan. Isto je utvrđeno i u slučaju odnosa između CCI LMA ${ }^{-1}$ i koncentracije klorofila (Tablica 4).

Koeficijent determinacije, nagib pravca i Y odsječak uniformne regresijske jednadžbe konstruirane na temelju lišća porijeklom iz oba tretmana bili su vrlo slični kao kod jednadžbi koje opisuju zasebni odnos CCI-a i koncentracije klorofila u lišću porijeklom iz kontrolnog, odnosno sušnog tretmana. Isto je utvrđeno i prilikom primjene CCI LMA ${ }^{-1}$ kao nezavisne varijable (Tablica 2 ).

\section{Odnos između klorofilnog indeksa i koncentracije karotenoida - Relationship between chlorophyll content index and carotenoid concentrations}

Kod lišća porijeklom iz oba tretmana između izmjerenih vrijednosti CCI-a i koncentracije karotenoida utvrđene su visoko signifikantne $(p<0,001)$ korelacije. Koeficijenti determinacije $\left(r^{2}\right)$ ukazuju da je u lišću kontrolnih i sušom tretiranih biljaka 54 i 43 \% varijacije u koncentraciji karotenoida objašnjeno na temelju izmjerenih vrijednosti CCIa (Slika 5a i Tablica 3).

Na temelju korigiranoga CCI-a sa specifičnom lisnom masom (CCI LMA-1) moguće je objasniti 63 \% (lišće kontrolnih biljaka) i 58 \% (lišće sušom tretiranih biljaka) varijacije u koncentraciji karotenoida (Slika 5b i Tablica 3).

Prema rezultatima ANCOVA-e utjecaj tretmana na parametre korelacijskih jednadžbi (nagibe pravaca i Y odsječke)

Tablica 3. Kalibracijske jednadžbe (linearne regresijske jednadžbe) konstruirane na temelju klorofilnog indeksa u lišću (CCI), odnosno klorofilnog indeksa u lišću korigiranog sa specifičnom lisnom masom (CCI LMA ${ }^{-1}$ ) i stvarne koncentracije ukupnih karotenoida u lišću biljaka porijeklom iz kontrolnog i sušnog tretmana. Jednadžbe pretvaraju klorofilni indeks (CCI) u koncentraciju ukupnih karotenoida u lišću (Car).

Table 3. Calibration equations (linear regression equations) constructed based on the chlorophyll content index (CCI), as well as chlorophyll content index corrected by specific leaf mass (CCI $\mathrm{LMA}^{-1}$ ) and the actual concentrations of total carotenoid in leaves of plants originating from control and drought treatment. The equations convert the chlorophyll content index (CCI) into the total carotenoid concentrations in leaves (Car).

\begin{tabular}{|c|c|c|c|c|c|c|}
\hline $\begin{array}{l}\text { Porijeklo } \\
\text { uzorkovanoga lišća } \\
\text { Origin of the sampled } \\
\text { leaves }\end{array}$ & $\begin{array}{l}\text { Jednadžbe s CCI kao } \\
\text { nezavisnom varijablom } \\
\text { Equations with CCI as } \\
\text { independent variable }\end{array}$ & $p$ & $r^{2}$ & $\begin{array}{c}\text { Jednadžbe s CCI LMA-1 } \\
\text { kao nezavisnom varijablom } \\
\text { Equations with CCI LMA }{ }^{-1} \text { as } \\
\text { independent variable }\end{array}$ & $p$ & $r^{2}$ \\
\hline $\begin{array}{l}\text { Kontrolni tretman }(\mathrm{n}=26) \\
\text { Control treatment }\end{array}$ & Car $=0,017 \times \mathrm{CCl}+0,34$ & $<0,001$ & 0,54 & Car $=2,281 \times \mathrm{CCI} \mathrm{LMA}^{-1}+0,32$ & $<0,001$ & 0,63 \\
\hline $\begin{array}{l}\text { Sušni tretman }(\mathrm{n}=34) \\
\text { Drought treatment }\end{array}$ & Car $=0,011 \times \mathrm{CCl}+0,43$ & $<0,001$ & 0,43 & Car $=1,932 \times \mathrm{CCl} \mathrm{LMA}^{-1}+0,38$ & $<0,001$ & 0,58 \\
\hline $\begin{array}{l}\text { Oba tretmana }(\mathrm{n}=60) \\
\text { Both treatments }\end{array}$ & Car $=0,013 \times \mathrm{CCl}+0,40$ & $<0,001$ & 0,52 & Car $=2,098 \times \mathrm{CCI} \mathrm{LMA}^{-1}+0,35$ & $<0,001$ & 0,64 \\
\hline
\end{tabular}


Tablica 4. Razine signifikantnosti $(p)$ dobivene pomoću ANCOVA-e kojom su testirane razlike u Y-odsječcima i nagibima pravaca kalibracijskih jednadžbi koje opisuju odnos između klorofilnog indeksa i koncentracije klorofila, odnosno karotenoida u lišću porijeklom iz kontrolnog ( $n=26)$ i sušnog $(n=34)$ tretmana. Na razlike u nagibima pravaca ukazuje signifikantna interakcija; tretman x CCI, odnosno tretman x CCI LMA-1. Samo u slučaju ako interakcija nije signifikantna opravdano je interpretirati razlike (faktor tretmana) između Y-odsječaka.

Table 4. ANCOVA significance values $(p)$ for differences in Y-intercepts and slopes of the calibration equations (which describing the relationship between the chlorophyll content index and the chlorophyll and carotenoid concentrations) constructed based on leaves originating from control ( $n=26)$ and drought $(n=34)$ treatments. A significant interaction (Treatment $x$ CCI or Treatment $\times$ CCI LMA ${ }^{-1}$ ) indicates differences in slope. Only if the interaction is not significant can differences in the Y-intercept (treatment factor) be interpreted.

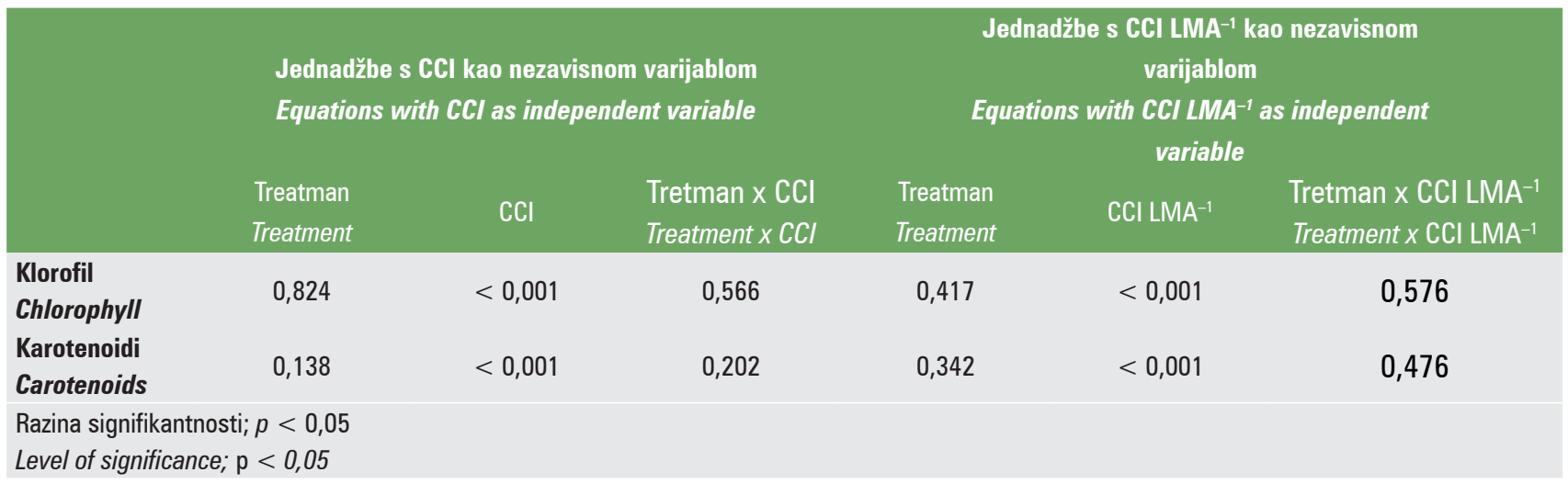

koje opisuju odnos između CCI-a i koncentracije karotenoida nije bila statistički značajna. Isto je utvrđeno i u slučaju odnosa između CCI LMA ${ }^{-1}$ i koncentracije karotenoida (Tablica 4).

Koeficijent determinacije, nagib pravca i Y odsječak uniformne regresijske jednadžbe konstruirane na temelju lišća porijeklom iz oba tretmana bili su vrlo slični kao kod jednadžbi koje opisuju zasebni odnos CCI-a i koncentracije karotenoida u lišću porijeklom iz kontrolnoga, odnosno iz sušnoga tretmana. Isto je utvrđeno i prilikom upotrebe CCI LMA $^{-1}$ kao nezavisne varijable (Tablica 3 ).

\section{RASPRAVA DISCUSSION}

Vegetativni rast istraživanih biljaka u oba tretmana bio je prilično intenzivan. To se ogleda u izrazitoj aktivnosti vršnoga meristema, što je rezultiralo intenzivnom sukcesivnom produkcijom vršnih izbojaka, karakterističnom za hrast lužnjak koji se uzgaja u optimalnim uvjetima (Le Hir i dr. 2005). Međutim, nakon prvog ljetnog porasta, početak sukcesivnoga rasta vršnih izbojaka u sušnom tretmanu zaostao je u odnosu na kontrolni tretman (Slika 1). Takav rezultat u skladu je s rezultatima ranijih istraživanja, prema kojima se sukcesivna produkcija vršnih izbojaka pod utjecajem sušnog stresa značajno usporava i odgađa za post sušno razdoblje (Spiess i dr. 2012; Kuster i dr. 2014). U skladu s tim, uzorkovano lišće iz sušnog tretmana u prosjeku je bilo nešto mlađe u odnosu na ono iz kontrolnog tretmana.

Prema dobivenim rezultatima, sredinom jeseni, pred kraj vegetacijskoga razdoblja (27. listopada) koncentracija klorofila i karotenoida u lišću biljaka koje su tijekom prvoga dijela vegetacijskoga razdoblja bile izložene dugotrajnoj suši bila je značajno viša nego u lišću biljaka iz kontrolnog tretmana koje su tijekom cijele vegetacijske sezone bile opskrbljene s optimalnom količinom vode (Tablica 1). Prema Arend i dr. (2016b) takav rezultat može biti posljedica odgođenog jesenskog starenja lišća kod biljaka koje su tijekom vegetacijskoga razdoblja pretrpile sušni stres. To je povezano $s$ dodatnom stimulacijom fotosintetske aktivnosti u post sušnom razdoblju nakon popuštanja sušnog stresa (Hagedorn i dr. 2016). Povećanu koncentraciju karotenoida u lišću biljaka koje su pretrpjele sušni stres moguće je povezati s njihovom ulogom u spriječavanju oksidacijskog stresa i popravka oštećenog fotosintetskog aparata (Peñuelas i Filella 1998; Lawlor 2001).

U oba tretmana, laboratorijski utvrđene koncentracije klorofila i karotenoida bile su u snažnoj vezi s CCI uz prilično visoke koeficijente determinacije (Tablice 2 i 3 ). To je u skladu s rezultatima ranijih istraživanja provedenih na šumskom drveću (Cate i Perkins 2003; Van den Berg i Perkins 2004; Jifon i dr. 2005; Percival i dr. 2008; Silla i dr. 2010). Unatoč statistički značajnim razlikama između tretmana s obzirom na koncentraciju fotosintetskih pigmenata i klorofilnoga indeksa (Tablica 1), rezultati ANCOVA-e ne ukazuju na to da tretman značajno utječe na razlike u Y-odsječcima i nagibima pravaca kalibracijskih jednadžbi koje opisuju odnos CCI-a i koncentracije klorofila, odnosno karotenoida (Tablica 4). Prema tomu, dugotrajno sušno razdoblje vjerojatno nije značajnije utjecalo na odnos između CCI-a i koncentracije fotosintetskih pigmenata u lišću. U skladu s tim, bilo je opravdano konstruirati uniformne kalibracijske jednadžbe na temelju lišća uzorkovanoga iz oba tretmana (Tablice 2 i 3 ).

Izostanak značajnog utjecaja dugotrajnog sušnog razdoblja na odnos CCI-a i koncentracije fotosintetskih pigmenata 
vjerojatno je posljedica dinamike vegetativnoga rasta istraživanih biljaka koja je bila sinkronizirana s dinamikom kretanja vlage u tlu. Prema tomu, sukcesivna produkcija vršnih izbojaka s pripadajućim lišćem u oba tretmana odvijala se uglavnom u vrijeme optimalne opskrbljenosti biljaka vodom (Slika 1). U skladu s tim, producirano lišće u oba tretmana imalo je podjednaku LMA (Tablica 1). Prema tomu, moguće je pretpostaviti da je i utjecaj strukturnih/ optičkih značajki lišća (Richardson i dr. 2002) na očitane vrijednosti CCI-a bio podjednak u oba tretmana. Upravo je to moglo rezultirati izostankom očekivanog utjecaja suše na koeficijente kalibracijskih jednadžbi koje opisuju odnos CCI-a i koncentracije fotosintetskih pigmenata.

Prema dobivenim rezultatima koncentraciju fotosintetskih pigmenata u lišću hrasta lužnjaka moguće je preciznije procijeniti ako se očitana vrijednost CCI-a korigira s LMA. Na to ukazuju prilično veći koeficijenti determinacije kalibracijskih jednadžbi koje opisuju odnos CCI LMA-1 i koncentracije fotosintetskih pigmenata u odnosu na koeficijente determinacije koji opisuju odnos CCI-a i koncentracije fotosintetskih pigmenata (Tablica 2 i 3 ). Takvo unapređenje koeficijenata determinacije može biti rezultat ublažavanja negativnog utjecaja različite starosti uzorkovanoga lišća na preciznost rada klorofilmetra, odnosno očitanja CCI-a. Prema Peng i dr. (1993) utjecaj različite starosti lišća na preciznost procjene klorofilnog indeksa s ciljem što preciznijeg utvrđivanja koncentracije dušika u lišću moguće je poboljšati upravo primjenom CCI-a korigiranoga s LMA. Štoviše, kod nekih vrsta iz roda Quercus uključivanje LMA u kalibracijske jednadžbe konstruirane na temelju lišća različite starosti također je rezultiralo poboljšanjem koeficijenata determinacije (Silla i dr. 2010). U slučaju korekcije CCI-a s LMA te uključivanja LMA kao dodatne nezavisne varijable u kalibracijske jednadžbe nužno je obaviti i uzorkovanje lišća prilikom izmjere CCI-a. To je potrebno obaviti radi utvrđivanja LMA istoga lišća na kojemu je izmjeren i CCI. U tom slučaju metoda klorofilmetrije zbog potrebe za uzorkovanjem lišća (destrukcijom biljnoga materijala) i njegove dodatne laboratorijske obrade nema tako izražene prednosti u vidu brzine, jednostavnosti, cijene i nedestruktivnosti u odnosu na standardne laboratorijske metode.

\section{ZAKLJUČCI}

\section{CONCLUSIONS}

Na temelju dobivenih rezultata, parametri kalibracijskih jednadžbi koje opisuju odnos CCI-a i koncentracije fotosintetskih pigmenata (klorofila i karotenoida) nisu bili utjecani sušnim tretmanom. Prema tomu, klorofilmetar CCM-200 uz primjenu odgovarajućih kalibracijskih jednadžbi predstavlja pouzdan alat za procjenu fotosintetskih pigmenata u lišću hrasta lužnjaka koje je tijekom vegetacijskoga razdoblja bilo izloženo dugotrajnom sušnom razdoblju. Na temelju korigiranog klorofilnog indeksa sa specifičnom lisnom masom moguće je povećati preciznost procjene koncentracije fotosintetskih pigmenata pomoću klorofilmetra. Međutim, u tom slučaju prednost klorofilmetrije u odnosu na standardne laboratorijske metode nije u potpunosti izražena.

\section{ZAHVALA \\ ACKNOWLEDGEMENTS}

Ovo istraživanje provedeno je u sklopu istraživačkog projekta "Fenotipski i epigenetski odgovor na sušni stres i prilagodljivost populacija hrasta lužnjaka (Quercus robur L.) uzduž gradijenta zemljopisne širine - PerdaQuercus" kojega financira Hrvatska zaklada za znanost. Prikazani rezultati sastavni su dio projektne aktivnosti 4.2. izmjere morfoloških svojstava listova i biokemijske analize listova u sklopu projektnoga cilja 4. utvrditi fenotipski odgovor na sušni stres.

\section{LITERATURA}

\section{REFERENCES}

- Arend, M., A. Gessler, M. Schaub, 2016a The influence of the soil on spring and autumn phenology in European beech. Tree Physiol, 36: 78-85.

- Arend, M., K. Sever, E. Pflug, A. Gessler, M. Schaub, 2016b: Seasonal photosynthetic response of European beech to severe summer drought: Limitation, recovery and post-drought stimulation. Agr Forest Meterol, 220: 83-89.

- Aspelmeier, S., 2001: Genotypic variation in drought response of silver birch (Betula pendula Roth). Georg-August-Universität zu Göttingen. Disertacija, str. 103.

- Baule, H., C. Fricker, 1970: The fertilizer treatment of forest trees. Verlagsgesellschaft mbH, München.

- Bruisna, J., 1961: A comment on the spectrophotometric determination of chlorophyll. Biochem. Biophys Acta, 52: 576-578.

- Cate, T. M., T. D. Perkins, 2003: Chlorophyll content monitoring in sugar maple (Acer saccharum). Tree Physiol, 23: 10771079.

- Chang, S. X., D. J. Robison, 2003: nondestructive and rapid estimation of hardwood foliar nitrogen status using the SPAD-502 chlorophyll meter. For Ecol Manage, 181: 337-338.

- Fridley, J. D.,2012; Extended leaf phenology and the autumn niche in deciduous forest invasions. Nature, 485: 359-362.

- Hagedorn, F., J. Joseph, M. Peter, J. Luster, K. Pritsch, U. Geppert, R. Kerner, V. Molinier, S. Egli, M. Schaub, J.F. Liu, M. Li, K.Sever, M. Weiler, R. T. W. Siegwolf, A. Gessler, M. Arend, 2016: Recovery of trees from drought depends on belowground sink control. Nature plants, doi: 10.1038/NPLANTS.2016.111

- Hiscox, J. D., Israelstam, G. F., 1979: A method for the extraction of chlorophyll from leaf tissue without maceration. Can J Bot, 57: 1332-1334.

- Inskeep, W. P., P. R. Bloom, 1985: Extinction coefficients of chlorophyll a and b in N,N-dimethylformamide and $80 \%$ acetone. Plant Physiol, 77: 483-485. 
- Jifon, J. L., J. P. Syvertsen, E. Whaley, 2005: Growth environmentand leaf anatomy affect nondestructive estimates of chlorophyll and nitrogen in Citrus sp. leaves. J Amer Soc Hor Sci, 130: 152-158.

- Kuster, T. M., M. Dobbertin, M. S. Günthardt-Goerg, M. Schaub, M. Arend, 2014: A phenological timetable of Oak growth under experimental drought and air warming. PLoS ONE, 9(2):e89724. doi:10.1371/journal.pone.0089724.

- Lawlor, D. W., 2001: Photosyntesis. $3^{\text {rd }}$ Edition. Scientific Publishers Limited, Oxford, U.K.

- Le Hir, R., S. Pelleschi-Traverien, J. D. Viemont, N. Leduc, 2005: Sourse synthase expression pattern in the rhytmically growing shoot of common oak (Quercus robur L.). Ann For Sci, 62: 585 591.

- Lichtenthaler, H. K., 1987: Chlorophylls and carotenoids: pigments of photosynthetic biomembranes Methods Enzimol, 148: 350-382.

- Peng, S., Garcia, F. V., Laza, R. C., Cassman, K. G., 1993: Adjustment for specific leaf weight improves chlorophyll meter's estimate of rice leaf nitrogen concentration. Agron J, 85: 987-990.

- Peñuelas, J., I. Filella, 1998: Visible and near-infrared reflectance techniques for diagnosing plant physiological status. Trends in Plant Science, 3: 151-156.

- Percival, G. C., I. P. Keary, K. Noviss, 2008: The potential of a chlorophyll content SPAD meter to quantify nutrient stress in foliar tissue os Sycamore (Acer pseudoplatanus), English oak (Quercus robur), and European beech (Fagus sylvatica). Arboriculture and Urban Forestry, 34: 89-100.
- Potočić, N., 2006: Utjecaj gnojidbe dušikom na rast i razvoj klonova nekih vrsta topola (Populus ssp.) u porječju Drave kod Varaždina. Šumarski fakultet Zagreb. Disertacija, str. 210.

- Richardson, A. D., Duigan S. P., and Berlyn G. P., 2002: An evaluation of non-invasive methods to estimate foliar chlorophyll content. New Phytol, 153: 185-194.

- Schmal, J. L., D. F. Jacobs, C. O’Reilly, 2011: Nitrogen budgeting and quality of exponentially fertilized Quercus robur seedlings in Ireland. Eur J For Res, 130: 557-567.

- Seletković, I., 2006: Utjecaj gnojidbe dušikom, fosforom i kalijem na rast i razvoj sadnica hrasta lužnjaka (Quercus robur L.). Šumarski fakultet Zagreb. Disertacija, str. 134.

- Silla, F., A. González-Gil, M. E. González-Molina, S. Mediavilla, A. Escudero, 2010: Estimation of chlorophyll in Quercus leaves using a portable chlorophyll meter: effects of species and leaf age. Ann For Sci, 67:108. doi: 10.1051/forest/2009093.

- Spiess, N., M. Oufir, I. Matusikova, M. Stierschneider, D. Kopecky, 2012: Ecophysiological and transcriptomic responses of oak (Quercus robur) to long-term drought exposure and rewatering. Environ Exp Bot, 77: 117-126.

- Torres Neto, A., E. Campostrini, J. Gonc, A. Oliveira, R. E. Bressan, 2005: Photosynthetic pigments, nitrogen, chlorophyll a fluorescence and SPAD-502 readings in coffee leaves. Sci Hort, 104: 199-209.

- Van den Berg, A. K., T. D. Perkins, 2004: Evaluation of a portable chlorophyll meter to estimate chlorophyll and nitrogen contents in sugar maple (Acer saccharum Marsh.) leaves. For Ecol Manage, 200: 113-117.

\section{Summary}

The concentration of photosynthetic pigments (chlorophylls and carotenoids) in leaves of forest trees is a good indicator of the photosynthetic efficiency, level of nutrition with nitrogen and autumn leaf senescence. Thus the photosynthetic pigment concentrations is one of the most significant parameters related to the physiological status of plant. Change in pigment concentrations of leaves indicate presence of environmental stress. Well-timed detection of environmental stress play a crucial role in preventing damage on seedlings and saplings in forest nurseries and wood mass production in forest cultures and plantations.

Traditional methods for determining the concentrations of photosynthetic pigments represent an obstacle to continuous monitoring concentrations of photosynthetic pigment in leaves of forest trees, primarily because they are relatively expensive, long lasting and require destruction of plant material. However, portable optical chlorophyll meters such as CCM-200 (Opti-Sciences, Tyngsboro, Massachusetts, USA) and SPAD-502 (Minolta Camera Co., Osaka, Japan) is a reliable alternative to traditional laboratory methods. To use chlorophyll meters as a tool for estimating photosynthetic pigment concentrations in leaves, it is necessary to construct regression equations (calibration equations) that reliably describe the relationships between the relative index of the total chlorophyll content in leaves (CCI) and the total pigment concentrations in leaves, determined by standard laboratory methods.

In the present study, we set up experiment to establish the ability of the hand-held CCM-200 chlorophyll meter to accurately estimate the content of the photosynthetic pigments in leaves of Quercus robur $\mathrm{L}$. with contrast level of soil moisture. The objectives of the present work were: (i) determine whether the long-lasting drought period significantly influences the relationship between the CCI obtined by CCM-200 and the concentration of photosynthetic pigments (total chlorophyll and carotenoid); (ii) construct calibration equations for non-destructive estimation of photosynthetic pigments in Q. robur leaves; (iii) to analyse the improvement estimation of photosynthetic pigments concentration when CCI was corrected with specific leaf mass.

The research was carried out during the year 2015 on 60 two-years old plants grown in the greenhouse located in the Croatian Forestry Institute Jastrebarsko. Plant material was grown in 50 liter containers 
previously filled with soil originating from a natural oak stand. In the spring of the 2015 , at the beginning of the study the mean height of investigated plants was $23.9 \pm 4.8 \mathrm{~cm}$.

During the study, plant material was exposure to different level of soil moisture. In control treatment soil water content was kept above field capacity, while in drought treatment plants were exposed to water reduction during 112 days ( $1^{\text {st }}$ of April $-21^{\text {st }}$ of July). In second part of growing season $\left(22^{\text {nd }}\right.$ of July $-22^{\text {nd }}$ of October) in both treatments soil water content was kept above field capacity (Figure 1). Calibration equations, that describe relationship between relative chlorophyll content index measured with chlorophyll meter and actual photosynthetic pigment concentrations in sampled leaves (laboratory determined) at the end of growing season ( $27^{\text {th }}$ of October), were constructed for both treatments (Table 2 and 3; Figure 4 and 5).

Obtined results show that parameters of calibration equations were not affected by drought treatment (Table 4). Therefore, when using appropriate calibration equations, clorophyll meter CCM-200 can be considered as reliable tool for non-destructive estimation of total chlorophylls and carotenoids in $Q$. robur leaves, regardless of different soil water regimes during the growing season. Additionaly, this research confirmed that it is possible to improve the estimation of actual photosynthetic pigment concentration by using chlorophyll content index corrected with specific leaf mass (Table 2 and 3; Figure 4 and 5).

KEY WORDS: chlorophyllmeter CCM-200, relative leaf chlorophyll content index, specific leaf mass, total chlorophylls, carotenoids 